\title{
Relationship between Organizational Justice, Psychological Capital and Job Burnout: Empirical Evidence from Health Care Sector
}

\author{
Norhani Bakri ${ }^{1} \&$ Nazim Ali ${ }^{1}$ \\ ${ }^{1}$ Faculty of Management, Universiti Teknologi Malaysia, Malaysia \\ Correspondence: Nazim Ali, Faculty of Management, Universiti Teknologi Malaysia, Malaysia. E-mail: \\ nazimali1000@gmail.com
}

Received: May 21, 2015 Accepted: October 19, 2015 Online Published: October 26, 2015

doi:10.5539/ass.v11n25p84 URL: http://dx.doi.org/10.5539/ass.v11n25p84

\begin{abstract}
The objective of this current research was to investigate the mediator role of organizational justice between psychological capital and job burnout of nurses working in private sector hospitals of Islamabad and Peshawar, Pakistan. Data were gathered from two hundred and twenty three (223) female nurses of private hospitals of Islamabad and Peshawar of Pakistan. Mediating techniques recommended by Barron and Kenny (1986) were used for finding out the mediating effect of organizational justice between psychological capital and job burnout. Results revealed that organizational justice mediated the impact between psychological capita and job burnout of nurses working in Pakistan.
\end{abstract}

Keywords: organizational justice, psychological capital, job burnout, nurses, Pakistan

\section{Introduction}

One of the exclusive purposes of HR practices is to affect human behavior in organizations. However, the results are always not as expected. Factors could be many including distinctive individual capabilities like psychological capital. Burnout is one of these unexpected outcomes that is causing many organizational problems. Burnout is ubiquitous but "professionals working with human beings have a higher risk of burnout because of the greater responsibility felt towards human beings than objects" (Özler \& Atalay, 2011, p. 27). Nurses are among the groups that experience it. This is because of some major stressor including intense workload, irregular work hours causing irregular sleeping, looking after critical and fatal patients, dealing with the relatives of patients and necessity of providing them emotional support. Besides, they have to cope with the problems in their vocational relations, organizational shortcomings and scant resources, their own concerns of family sustenance, and incapability of allocating enough time for their private life while dealing with these problems cause job-related stress and tension (Özler \& Atalay, 2011). Studies in advanced countries have explored the impact of modern management practices on employee burnout (Godard, 2001; Ramsay, Scholarios, \& Harley, 2000). Our study postulates that the results of those studies may have generalizability but a recent study of the people of 16 Western European countries (Okulicz-Kozaryn, Holmes, \& Avery, 2014) concludes that people living in more liberal countries are happier on average than those in less liberal countries, but individually, conservatives are happier than liberals no matter where they live. This has necessitated the present empirical research with the aim to investigate as to what extent organization research in Pakistan validates the previous studies in the advanced countries and liberal societies.

By definition, burnout is "a common emotional fatigue (burnout) and a cynicism syndrome among the individuals who work face-to-face with people and do jobs that involve human process as compared to mechanic or technical process" (Christina Maslach \& Jackson, 1981).Burnout is not only a subjective reaction that emanates from endured job strain (Maslach, 1993), but could also be a reasoned response to the objective analysis of management practices (Maslach, Schaufeli, \& Leiter, 2001). Burnout is one of the negative predictors (others being job strain and turnover intentions) and is a part of an employee's occupational happiness that researchers have been paying increasing attention to measure employees well-being at workplace (2008) (Lyubomirsky, King, \& Diener, 2005; Yan \& Su, 2012; Zhang, Wu, Miao, Yan, \& Peng, 2013). Occupational happiness refers to the positive and negative emotional feelings of employees towards their jobs as well as their cognitive evaluations of their jobs (Diener, 2000; Judge, Thoresen, Bono, \& Patton, 2001; Wright \& Cropanzano, 2004). For some researchers it is a negative output of the interaction between employees and work environment 
(Fedai \& Yeter, 2010) that results in emotional withdrawal from the job and reduces feelings of personal accomplishment (Kroon, Van de Voorde, \& van Veldhoven, 2009; Maslach, et al., 2001). Scholars have empirically studied variables like job satisfaction, role conflict and uncertainty, absenteeism, expectations on the job, organizational support and politics, and the like (Özler \& Atalay, 2011). However, how organizational justice that pervades many variables which affect burnout, has hardly been touched upon, especially in the context of $3^{\text {rd }}$ world countries.

Research scholars have broadened the scope of burnout research from the individual job context to the broader organizational factors like management practices, organizational configuration, layout and even the wider organizational environment (Schaufeli, 2006). Violation of psychological contract at different levels in the employee's work context, the individual job level, social relationship with management, colleagues, and with the organization impact withdrawal behaviors and emotional exhaustion (Schaufeli, 2006). Besides, some management practices, like high performance work practices or management by objectives, poor management, downsizing have been researched as organization level stressors (Kroon et al., 2009). Similarly, organizational justice and contextual job demands have also been studied as stressor that may cause burnout (Noblet \& Rodwell, 2008). It has been concluded that generally employee's overall assessment of organizational justice contributes to mitigate job stress (Noblet \& Rodwell, 2008).

Employees always observe and feel the treatment they receive during their active service in an organization. This is what the psychologist justice perceptions. By definition it the degree to which individuals believe the ways they are treated within organizations are reasonable, impartial, and are not against human dignity, morality and ethics (Cole, Bernerth, Walter, \& Holt, 2010; Cropanzano, Bowen, \& Gilliland, 2007). It is generally believed that non-observance of entertaining this perceptions of the employees affect their attitudes towards work and their ability to cope with work demands (Judge \& Colquitt, 2004; Maslach \& Leiter, 2008).

The debate on the types of organizational justice(Cole, et al., 2010) is fruitful for understanding its dimensions, the current study only mentions the four types elaborated by Colquitt, and Judge and Colquitt (Colquitt, 2001; Judge \& Colquitt, 2004). According to them, first, employees experience distributive justice when organization allocates outcomes on fairness and equity; second, procedural justice when organizational processes in decision making and allocation of outcomes are made equity and fairness; third, interpersonal justice when employees feel they are treated with dignity, respect, and consideration; and finally, informational justice when information shared with the individual employees are adequate, timely, and based on truth and honesty. Keeping all these dimensions in mind, researchers have explored direct associations between organization justice and various outcomes (Gilliland, 2008; Zapata-Phelan, Colquitt, Scott, \& Livingston, 2009). These researchers complain exploring direct association has some way or the other neglected 'the underlying process of how organization justice reactions motivate responses' (Gilliland, 2008). Addressing this gap Cole et al. have explored its mediating role (Cole et al., 2010).

To affect employees' occupational happiness, it is imperative to reduce job burnout and employee's psychological capital is considered one of the mechanisms (Peng et al., 2013). Psychological capital is considered a positive psychology and positive organization behavior (Luthans \& Youssef, 2004). According to them it is "a positive state of mind exhibited during the growth and development of an individual". They further elaborate it by explaining its four components of self-efficacy, optimism, resiliency, and hope. By self-efficacy they mean the individual's potential of facing challenge, the confidence to perform an assigned task and the determination to succeed. By optimism they mean an individual's willingness to perform positively and uphold a positive attitude towards the present and future. By resiliency they mean the potential of an individual to recover quickly from setbacks, adversities, setbacks, failures and learn from such events. And by hope they mean an individual's motivational state of mind that keeps them on track in achieving the desired aims.

A number of studies (Avey, Patera, \& West, 2006; Luthans, Avolio, Walumbwa, \& Li, 2005; Luthans, Luthans, \& Luthans, 2004) have investigated the relationship between the various dimensions of psychological capital and attitudes-absenteeism, turnover intentions, and perceived job performance of the workforce. Similarly, some studies have looked into the relationship between burnout and psychological capital (Luo \& Hao, 2010; Luthans et al., 2005; Peng et al., 2013). Researchers opine that psychological capital effectively reduces the chances of burnout (Luo \& Hao, 2010; Luthans et al., 2004). However, Peng et al. conclude that "the body of research concerning the relationship between psychological capital and job burnout remains relatively small" (Peng et al., 2013). To the best of our knowledge, there are no studies that have investigated the mediator role of organizational justice between psychological capital and job burnout. That's why; this study was conducted to contribute to the existing treasure of literature by finding out the mediating effect of organizational justice between psychological capital and job burnout. 


\section{Objectives of the Study}

a) To investigate the relationship between psychological capital, organizational justice and job burnout of female nurses working in Pakistani private sector hospitals.

b) To investigate the mediator role of organizational justice between psychological capital and job burnout of female nurses working in Pakistani private sector hospitals.

The following proposed model was tested by taking sample of nurses working in Pakistani hospitals.

PROPOSED MODEL

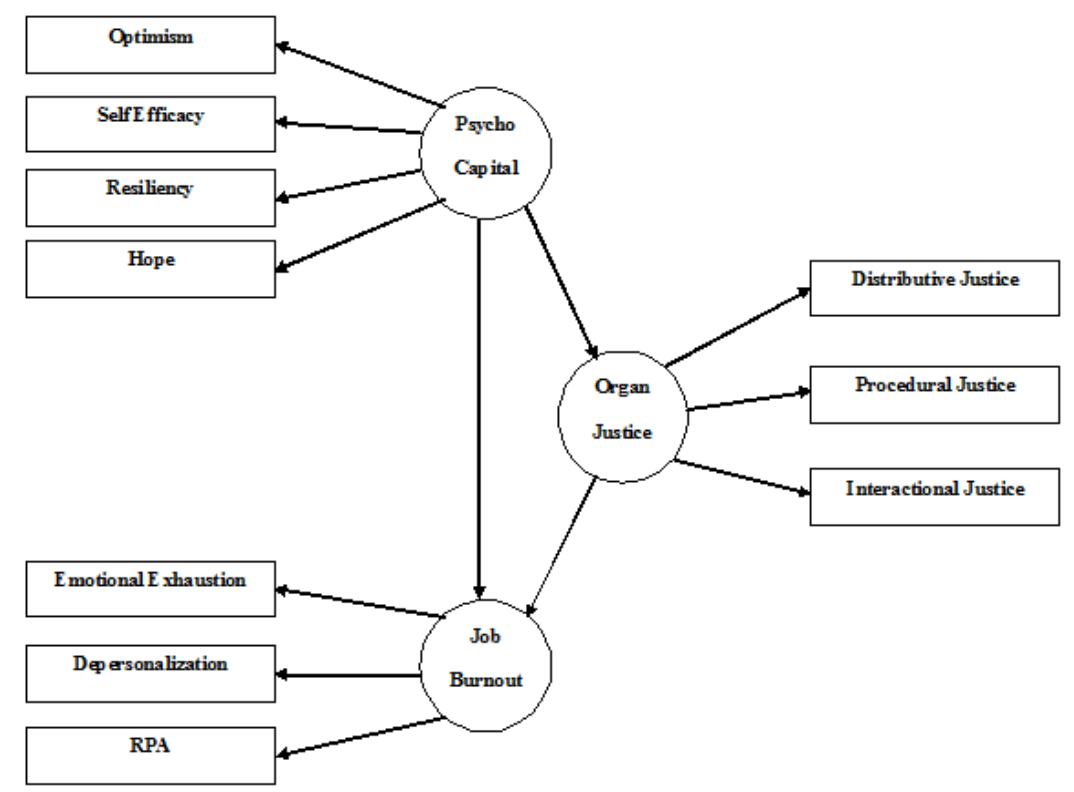

Note: Psycho $=$ Psychological; Organ $=$ Organizationa $;$ RPA $=$ Reduced Personal Accomplishment

Figure 1.

\section{Medothodoly}

\subsection{Sample of the Study}

Data were gathered from two hundered and twenty three (223) female nurses working in private sector hospitals of Islamabad and Peshawar by self administered questionnaire. The nurses were first distributed a cover letter that highlighted the objectives of the study. So data were collected from those nurses who showed a willingness to participate in the study.

\subsection{Data Analysis}

Data was analysed through SPSS ( $18^{\text {th }}$ edition) and Amos ( $18^{\text {th }}$ edition). Barron and Kenny (1986) mediating techniques were used to test the mediating effect of organizational justice between psychological capital and job burnout of nurese working in private sector hospitals of islamabad and peshawar of Pakistan. According to barron and kenny, four conditions have to be fulfilled for mediator role. First, psychological capital must have a signficant impact on job burnout. Second, psychological capital must have a significant impact on organizational justice. Third, organizational justice must have a significant impact on job burnout. Last, organizational just should reduce the impact of psychological capital on job burnout. If the impact of psychological capital on job burnout after including the mediator reduced but still significant, it is called partial mediation. If the impact declines but not significant, it shows full mediation.

\subsection{Measures}

\subsubsection{Psychological Capital Questionnaire}

Psychological capital questionnaire adapted from Luthan et al. (2006) has four dimensions namely, optimism, resilience, hope and self-efficacy and six items for each dimension. Data were collected by using six point likert 
scale starting from 1 (Strongly Disagree) and ending at 6 (Strongly Agree).

\subsubsection{Job Burnout Inventory}

Job burnout inventory-general survey adapted from Maslach (1996) has three dimensions namely, depersonalization, emotional exhaustion and reduced personal accomplishment. This scale has 15 items. Each question was rated by seven point likert scale starting from 1 (never) and ending at 7 (every day).

\subsubsection{Organizational Justice Questionnaire}

Organizational justice questionnaire adapted from Schaufeli and Leiter (1996) has three dimensions namely, distributive justice, procedural justice and interactional justice. Each item was rated on seven point likert scale starting from 1 (Strongly Disagree) and ending at 7 (Strongly Agree).

\section{Results}

MODEL

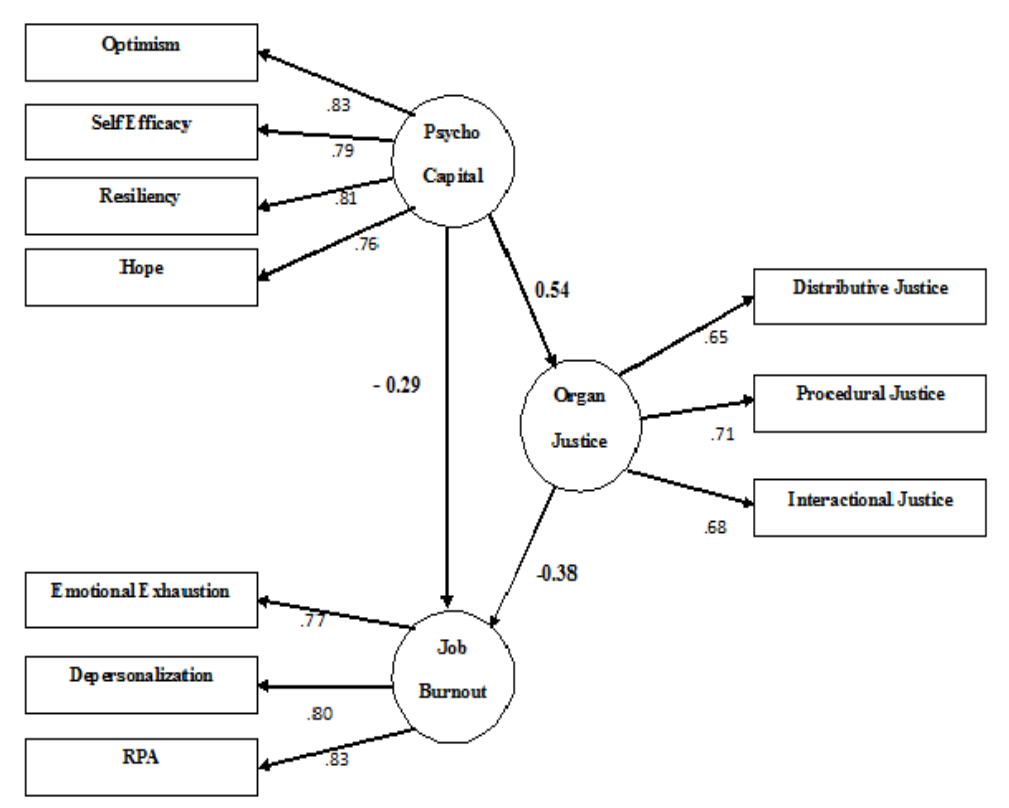

Note: Psycho = Psychological; Organ = Organizational; RPA = Reduced P'ers onal Accomplishment

Figure 2

The results shown in figure 2 revealed that organizational justice partially mediated the effect of psychological capital on job burnout of nurses working in Pakistani hospitals. The model was found significant and all values of chi square, GFI, CFI, RMR, RMSEA and NFI were found in acceptable range. Chi square was 86.562 with $\mathrm{df}=35$; probability level, 0.002 ; $\mathrm{GFI}=0.916$; $\mathrm{CFI}=0.934$; $\mathrm{RMR}=0.017$ and RMSEA $=0.021$. The direct path from psychological capital to job burnout showed a beta value of -0.48 , indicating that psychological capital had a significant impact on job burnout, thus satisfying the first condition for finding out the mediator role (Baron \& Kenny, 1986). The second condition was also satisfied when psychological capital showed a significant impact on organizational justice. Similarly third condition was also met when organizational justice explored a significant impact on job burnout.

\section{Conclusion}

The aim of this study was to investigate the mediator role of organizational justice between psychological capital and job burnout of nurses working in Pakistani private sector hospitals. For this purpose, data were collected from two hundred and twenty three (223) female nurses working in two big cities of Pakistan (Islamabad and Peshawar). Barron and Kenny's (1986) procedure for testing the mediator role was adopted. Data was analyzed through SPSS (18 edition) and Amos (18 edition). The results explored that organizational justice partially mediated the impact of psychological capital on job burnout. 


\section{References}

Avey, J. B., Patera, J. L., \& West, B. J. (2006). The implications of positive psychological capital on employee absenteeism. Journal of Leadership and Organizational Studies, 13(2), 42-60. http://dx.doi.org/10.1177/ 10717919070130020401

Baron, R. M., \& Kenny, D. A. (1986). The moderator-mediator variable distinction in social psychological research: Conceptual, strategic, and statistical considerations. Journal of personality and social psychology, 51(6), 1173. http://dx.doi.org/10.1037/0022-3514.51.6.1173

Cole, M. S., Bernerth, J. B., Walter, F., \& Holt, D. T. (2010). Organizational justice and individuals' withdrawal: Unlocking the influence of emotional exhaustion. Journal of Management Studies, 47(3), 367-390. http://dx.doi.org/10.1111/j.1467-6486.2009.00864.x

Colquitt, J. A. (2001). On the dimensionality of organizational justice: A construct validation of a measure. Journal of Applied Psychology, 86, 386-400. http://dx.doi.org/10.1037/0021-9010.86.3.386

Cropanzano, R, Bowen, D. E., \& Gilliland, S. W. (2007). The management of organizational justice. Academy of Management Perspectives, 21, 34-48. http://dx.doi.org/10.5465/AMP.2007.27895338

Diener, E. (2000). Subjective well-being: The science of happiness and a proposal for a national index. American Psychologist, 55(1), 34-43. http://dx.doi.org/10.1037/0003-066X.55.1.34

Fedai, Ç. M., \& Yeter, D. (2010). The impacts of structural and psychological empowerment on burnout: A research of staff nurses in Turkish State Hospitals. Canadian Social Sciences, 6(4), 63-72.

Gilliland, S. (2008). The tails of justice: A critical examination of the dimensionality of organizational justice constructs. Human Resource Management Review, 18, 271-281. http://dx.doi.org/10.1016/j.hrmr.2008. 08.001

Godard, J. (2001). High performance and the transformation of work? The implications of alternative work practices for the experience and outcomes of work. Industrial \& Labor Relations Review, 54, 776-805. http://dx.doi.org/10.1177/001979390105400402

Hakanen, J. J., Perhoniemi, R., \& Toppinen-Tanner, S. (2008). Positive gain spirals at work: From job resources to work engagement, personal initiative and work-unit innovativeness. Journal of Vocational Behavior, 73(1), 78-91. http://dx.doi.org/10.1016/j.jvb.2008.01.003

Judge, T. A., \& Colquitt, J. A. (2004). Organizational justice and stress: The mediating role of work-family conflict. Journal of Applied Psychology, 89, 395-404. http://dx.doi.org/10.1037/0021-9010.89.3.395

Judge, T. A., Thoresen, C. J., Bono, J. E., \& Patton, G. K. (2001). The job satisfaction-job performance relationship: A qualitative and quantitative review. Psychological Bulletin, 127(3), 376-407. http://dx.doi. org/10.1037/0033-2909.127.3.376

Kroon, B., Van de Voorde, K., \& van Veldhoven, M. J. P. M. (2009). Cross-level effects of high-performance work practices on burnout: Two counteracting mediating mechanisms compared. Personnel Review, 38(5), 509-525. http://dx.doi.org/10.1108/00483480910978027

Luo, H., \& Hao, Z. H. (2010). The relationships among psychological capital, job burnout and turnover intention in 466 nurses. Chinese Journal of Nurse, 45, 933-935.

Luthans, F., \& Youssef, C. (2004). Human, social, and now positive psychological capital management: Investing in people for competitive advantage. Organizational Dynamics, 33(2), 143-160. http://dx.doi.org /10.1016/j.orgdyn.2004.01.003

Luthans, F., Avolio, B. J., Walumbwa, F. O., \& Li, W. (2005). The psychological capital of Chinese workers: Exploring the relationship with performance. Management and Organization Review, 1(2), 249-271. http://dx.doi.org/10.1111/j.1740-8784.2005.00011.x

Luthans, F., Luthans, K. W., \& Luthans, B. (2004). Positive psychological capital: Beyond human and social capital. Business Horizons, 47(1), 45-50. http://dx.doi.org/10.1016/j.bushor.2003.11.007

Luthans, F., Youssef, C. M., \& Avolio, B. J. (2006). Psychological capital: Developing the human competitive edge. Oxford University Press. http://dx.doi.org/10.1093/acprof:oso/9780195187526.001.0001

Lyubomirsky, S., King, L., \& Diener, E. (2005). The benefits of frequent positive affect: Does happiness lead to success? Psychological Bulletin, 131(6), 803-855. http://dx.doi.org/10.1037/0033-2909.131.6.803

Maslach, C. (1993). Burnout: A multidimensional perspective. In W. B. Schaufeli, C. Maslach, \& T. Marck 
(Eds.), Professional Burnout: Recent Developments in Theory and Research (pp. 1-16). Washington, DC: Taylor \& Francis.

Maslach, C. A., \& Leiter, M. P. (2008). Early predictors of job burnout and engagement. Journal of Applied Psychology, 93, 498-512. http://dx.doi.org/10.1037/0021-9010.93.3.498

Maslach, C., \& Jackson, S. E. (1981). The measurement of experienced burnout. Journal of Organizational Behavior, 2(2), 99-113. http://dx.doi.org/10.1002/job.4030020205

Maslach, C., Schaufeli, W. B., \& Leiter, M. P. (2001). Job burnout. Annual Review of Psychology, 52, 397-422. http://dx.doi.org/10.1146/annurev.psych.52.1.397

Noblet, A. J. , \& Rodwell, J. J. (2008). The relationship between organisational justice and job stress: Insights, issues and implications. In I. Houdtmont, \& S. Leka (Eds.), Occupational Health Psychology: European Perspectives on Research, Education and Practice (pp. 281-312). Nottingham: Nottingham University Press.

Okulicz-Kozaryn, A., Holmes, O., \& Avery, D. R. (2014). The subjective well-being political paradox: Happy welfare states and unhappy liberals. Journal of Applied Psychology. http://dx.doi.org/10.1037/a0037654

Özler, D. E., \& Atalay, C. G. (2011). A research to determine the relationship between organizational cynicism and burnout levels of employees in health sector. Business \& Management Review, 1(4), 26-38.

Peng, J. X., Jiang, X. H., Zhang, J. X., Xiao, R. X., Song, Y. Y., Feng, X., ... Miao, D. M. (2013). The impact of psychological capital on job burnout of Chinese nurses: The mediator role of organizational commitment. PLOS ONE, 8(12), 1-7. http://dx.doi.org/10.1371/journal.pone.0084193

Ramsay, H., Scholarios, D., \& Harley, B. (2000). Employees and high-performance work systems: Testing inside the black box. British Journal of Labour Relations, 38, 501-531. http://dx.doi.org/10.1111/1467-8543.00178

Schaufeli, W. B. (2006). The balance of give and take: Toward a social exchange model of burnout. Revue internationale de psychologie sociale, 19(1), 87-131.

Schaufeli, W. B., \& Leiter, M. P. (1996). Maslach burnout inventory-general survey. The Maslach burnout inventory-test manual, 1, 19-26.

Wright, T. A., \& Cropanzano, R. (2004). The role of psychological well-being in job performance: A fresh look at an age-old quest. Organizational Dynamics, 33(4), 338-351. http://dx.doi.org/10.1016/j.orgdyn.2004. 09.002

Yan, X., \& Su, J. (2012). Core self-evaluations mediators of the influence of social support on job involvement in hospital nurses. Social Indicators Research, 113(1), 299-306. http://dx.doi.org/10.1007/s11205-012 -0093-x

Zapata-Phelan, C. P., Colquitt, J. A., Scott, B. A., \& Livingston, B. (2009). Procedural justice, interactional justice, and task performance: The mediating role of intrinsic motivation. Organizational Behavior and Human Decision Processes, 108, 93-105. http://dx.doi.org/10.1016/j.obhdp.2008.08.001

Zhang, J., Wu, Q., Miao, D., Yan, X., \& Peng, J. (2013). The impact of core self-evaluations on job satisfaction: The mediator role of career commitment. Social Indicators Research, 1-14.

\section{Copyrights}

Copyright for this article is retained by the author(s), with first publication rights granted to the journal.

This is an open-access article distributed under the terms and conditions of the Creative Commons Attribution license (http://creativecommons.org/licenses/by/3.0/). 